\title{
The "Them" And "Us" Syndrome: Some Opportunities And Threats To Be Faced When Teachers Come From Certain Countries And Students Come From Others
}

\author{
Veronica Velo, (Email: v.velo@coventry.ac.uk), Coventry University, England
}

\begin{abstract}
Switzerland is a country with particularly strong immigration regulations, which obliges Hospitality Schools to very often restrict their recruitment for instructors to the local labour market. The students, however, mostly come from distant countries. These students naturally bring their own cultural backgrounds and mental programming, which is not necessarily compatible with those of their lecturers. This paper will study potential areas of misunderstandings and communication problems between students and teachers interacting in Swiss Hospitality Management Schools, due to their different cultural backgrounds.
\end{abstract}

\section{INTRODUCTION}

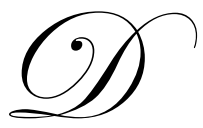

ue to strong immigration regulations, Swiss Hospitality Schools, as well as many other companies, privilege the hiring of local nationals or persons whose origin is from wealthy Western economies to fill the teaching positions. On the other hand, the student population tends to be more diverse, mostly constituted by young cosmopolitans travelling to Switzerland, attracted by the promising future that a Swiss degree could ensure for them. These conditions result in the day-to-day encounter of two not necessarily compatible groups. The first is composed of lecturers, who bring along a set of values that are basically the ones of Western developed economies; the second group is composed of students coming mostly from a patchwork of cultures with different values and assumptions about how the world is and how it functions.

This paper will reveal potential areas of misunderstandings and communication problems that could take place between students and teachers due to their different cultural backgrounds. Data has been collected in two of the leading Swiss Hospitality Management Institutions (Institut Hôtelier César Ritz in Le Bouveret and University Center César Ritz in Brig). These schools have been selected because of their high level of diversity in student population.

\section{CONCEPTUAL ANALYSIS}

Geert Hofstede (1980) was one of the pioneers together with Edward Hall (1976) in the study of the impact of the cultural dimension in the development of management and business. Hofstede's typologies (frameworks) opposing dichotomies (individualism vs collectivism, masculinity vs femininity, high vs low power distance, high vs low uncertainty avoidance and short vs long run orientation) offered to researchers the basis for multiple articles and studies. Fons Trompenaars in the 1990s borrowed Hofstede's approach and produced seven dimensions, some of which overlap with Hofstede's.

In this article we will use both Hofstede and Trompenaars dimensions to: (1) compare the cultures which the students come from using the above-mentioned frameworks for cultural analysis; and (2) predict areas of misunderstanding between teachers and students due to differences in cultural backgrounds. 


\section{THE CULTURAL DIMENSIONS}

According to Trompenaars, culture is the way that different societies have chosen to solve their own problems. It comprises the set of formal and informal rules that people in these societies have invented in order to survive as a homogeneous group. These rules are based on the notion of "good and evil" and are transmitted from generation to generation through the socialization process (Parsons, 1963).

Hofstede and Trompenaars have developed dimensions of cultural analysis according to which they were able to position many countries with regards to their mental programming (assumptions of their people about what "normal behaviour" is). As most of the time what is said to be "absolutely normal and desirable" for some cultures is being seen as "intolerable" by others, having a set of frameworks for categorising these perceptions has been extremely useful for researchers to facilitate the understanding of the cultural aspects of human life.

We will start our synthesis of the frameworks that we will use in our study by explaining individualism vs collectivism, which was created by Hofstede and taken up by Trompenaars. This dimension measures the relationship between the individual and the groups to which he or she belongs. In individualistic cultures, people are brought up to be independent, to fight for their own ideas and rights, to develop their own beliefs and not to report to anybody about their choices in life. On the opposite side, collectivistic people see themselves as part of different groups: religious community, family, company, etc. Their ideas and beliefs should be those of the groups to which they belong and their success in life is strongly linked to them as well.

The second dichotomy we will take for comparison will be the one Trompenaars used to describe how different cultures relate to the environment. People from some cultures interpret the world as an object to be analysed, understood and dominated. They are called cultures with internal locus of control. Other cultures just take the world as either a source of knowledge or as a source of fear, but which in any case is perceived as stronger than human nature. Those who perceive reality as something that comes from outside their own selves., and that therefore requires more adaptation than domination, are categorised as cultures with external locus of control. These terminologies have been borrowed by Trompenaars from the famous psychologist JB Rotter (1971).

Trompenaars included in his analysis a framework related to time. According to him, there are cultures where time is considered to be a sequence of passing events, not necessarily linked to each other. The past and the present are therefore not tightly related; they are independent. Each action has its place in time. These cultures are defined as sequential. On the other hand, there are cultures in which the present, the past and the future are closely interrelated. Many activities can take place at the same time, and what happened before will affect what is happening at the moment, as well as what will happen in the future. Past, present and future are all connected with each other and each determines or is a consequence of the others. These cultures are said to be synchronic.

Another of Hofstede's dimensions is femininity/masculinity, which has to do mainly with the way in which roles are distributed in society. In feminine cultures, women and men are supposed to assume interchangeable roles, whereas in masculine cultures, what women and men are supposed to do, think, feel, pursue and expect from life is determined and strongly differentiated. This dimension also regards the type of values held by these cultures. For example, in feminine societies, values traditionally attributed to women --such as modesty, caring (for the poor, for the ecological environment, etc.), consumption of fresh products, non-corruption, sexuality as a relationship (and not as an allowance), etc-- prevail.

The next framework, presented by Trompenaars, is universalism/particularism. This dimension describes how different cultures perceive the correct application of rules and regulations. In universalistic cultures, people respect their rules without exception and deviant behaviours with regards to these norms are punished without exception. The reason behind this strict behaviour is the necessity to reinforce the value of the law under the assumption that, without it, society would become out of control. In particularist cultures, rules and norms are perceived just a general guideline for behaviour, but they are not supposed to be followed without exceptions. Relationships count more. Rule applicability depends always on the situation, and also in the closeness between the 
"judge" and the person who has broken the law. A strict attachment to the law would be interpreted in particularist societies as a lack of sensitivity or even of common sense.

The next dimension, also from Trompenaars, has to do with the degree of involvement that people from different cultures show towards others. The dichotomy here takes place between diffuses and specifics. People in the former category take time to form attachments. The latter category includes people who immediately get in touch with strangers, but who do not keep them forever as friends. Another difference between specifics and diffuses is related to the domain of the issues shared. Diffuses take time to share experiences and objects with others, but when they do, this sharing includes all aspects of life. Specifics share fast, but only issues that have to do with particular aspects of life. Specifics would share working problems with working colleagues. But outside work, the relationship could be over, or of a very different nature.

Geert Hofstede introduced the concept of power distance. This dimension relates to how hierarchicallyoriented different cultures are. High power distance cultures are those where money and access to wealth are very unequally distributed. In cultures with low power distance the basic elements for living are ensured to everyone and those who are rich do not show off their status. This status is most of the time not as exorbitant as that of the richest and most powerful people in high power distance cultures.

The next dichotomy (from Trompenaars) has to do with status. Different cultures accord status in different ways. Some privilege achievements, meaning that respect is going to be given to those who can demonstrate they have done things well in the recent past (and that they are still able to perform), while others will give more importance to virtue (age, gender, class, education, etc.). Cultures where status is given according to virtue are said to be "ascribed" cultures. Those where status is granted to those who seem to be able of "doing well", are called "achieving" cultures.

Back to Hofstede's dimensions, we have uncertainty avoidance. This dimension measures the cultural predisposition to take risks. People from high uncertainty avoidance cultures dislike abnormal or original behaviours, stick to religious rules more tightly, and get attached to one or more of the following factors intended to reduce or control the unknown: technology (which allows us to deal with nature), law (that protects us from human behaviour) or religion (which helps us to accept our destiny and promises us a state of health and safety after death). Cultures with low uncertainty avoidance accept everyday anxiety more naturally.

Finally, we have Trompenaar's framework related to communication. It is called neturals vs emotionals. In neutral cultures, people express their feelings openly, seek in their interlocutors a direct response (they expect others to share their feelings) and do not express disagreement directly. In emotional cultures people consider that feelings should not be expressed openly because this could disturb others with problems that are none of their business. Openly expressing feelings is perceived as an act of immaturity and sometimes even as a weakness (the incapacity of controlling oneself). In these cultures, the interlocutor is expected just to understand the situation, but not to put himself in the shoes of the other person.

\section{EMPIRICAL ANALYSIS}

Having described the conceptual framework, we positioned the cultural origin of the population of the totality of the students of the two schools participating to the survey (456 students in Le Bouveret and Brig), and we categorised them into the frameworks described in the previous paragraphs. We did the same with the 46 lecturers teaching these students.

Then, we proceeded to the comparison of (a) the cultural positioning of the 456 students, and (b) the cultural positioning of the teachers. Finally, we were able to predict potential problems that teachers unable to adapt to the values of the student population would most probably have to face.

It is important to say that most teachers have been able to adapt to their students' cultures and mental programming very successfully, regardless their own origin. We are by no means stating that teachers coming from the same countries as the students have better relationships with them, but only that the personal values of the teachers 
that the students appreciate might be in tight connexion with those of their own cultures. We will then make comments based on some of the cross-cultural communication challenges to be faced by teachers with cultural backgrounds different from those of the student population, and who don't have personal characteristics compatible with the values of their students.

Following is our comparison of the cultural positioning of (a) the 456 students according to their national origin (positioned according to Trompenaar's and Hofstede's scales), and (b) the 46 teachers of these students (also positioned according to Trompenaar's and Hofstede's scales).

\section{Individualism Vs. Collectivism}

The following chart shows that most of the 456 students of the schools participating to the survey come from collectivist cultures, whereas most of their teachers come from individualistic ones.
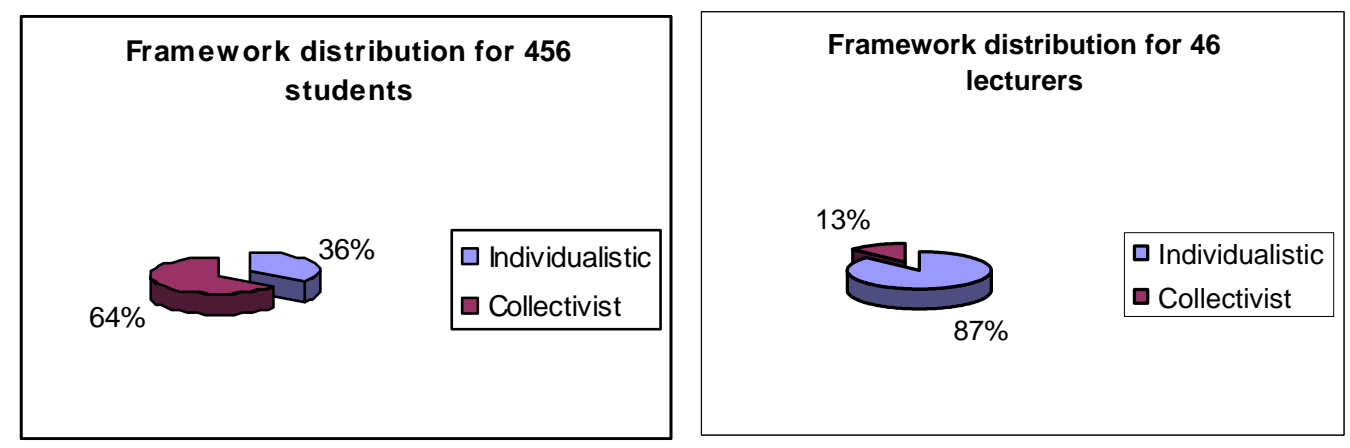

As said before, the fact that most teachers come from individualistic cultures is only due to immigration restrictions, which considerably reduce the possibility of getting a job in Switzerland for people from non- "Westerndeveloped" countries (unless the teacher gets married to a Swiss national or someone from another Western-developed country). Under these circumstances, some of the problems arising from the cultural mismatch between teachers and students with regards to collectivism and individualism could be:

\begin{tabular}{|c|c|}
\hline Teachers see students as... & Students see teachers as... \\
\hline - $\quad$ Lacking competitive (sportive) spirit & - $\quad$ Pushy \\
\hline - $\quad$ Ready to cheat in order to help their friends & - $\quad$ Aggressive \\
\hline $\begin{array}{l}\text { - Shy and unable to communicate their } \\
\text { achievements or background }\end{array}$ & - Lacking empathy \\
\hline $\begin{array}{ll} & \text { Always having "groupthink" and being } \\
\text { incapable of holding individual positions }\end{array}$ & - $\quad$ Rude or socially dysfunctional \\
\hline
\end{tabular}

Students might see individualistic teachers as arrogant and pushy because the lecturers expect them to show their knowledge off during class interactions and day-to-day activities. Teachers, on the other hand, might be surprised by the quietness of most students, who are too shy to participate, and this could be interpreted as a lack of interest from their side -or, even worse, as lack of any stimulating competitive spirit. Teachers could also feel frustrated when students privilege harmony in their friendship more than their own academic interests, for example when capable students risk their records and even their survival at school by cheating in the most creative ways. 


\section{Locus Of Control}

The following chart shows that most of the 456 students at the schools participating in the survey come from cultures with external locus of control. Nevertheless, most teachers come from cultures where locus of control comes from within the person.
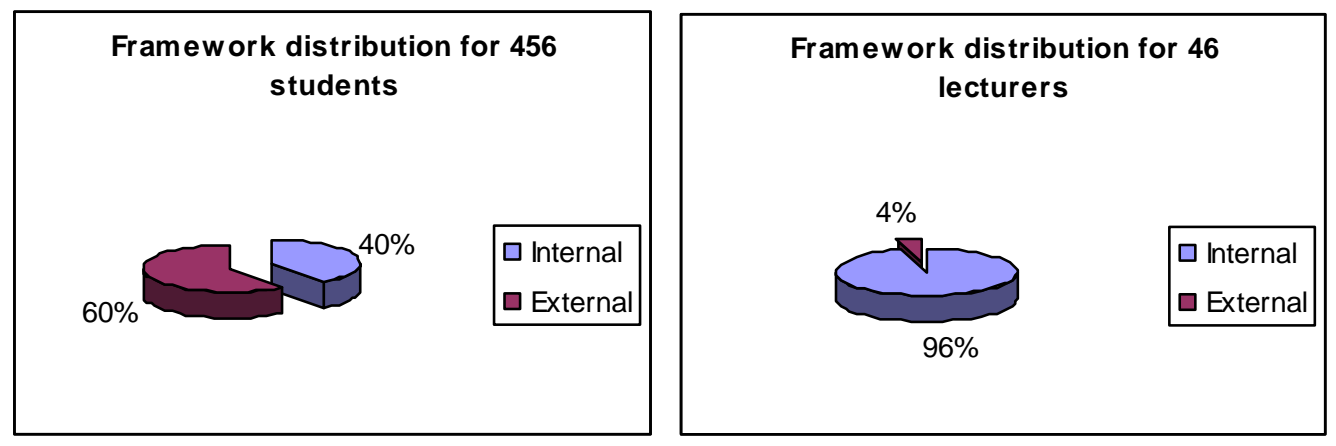

The consequences of this mismatch could be:

\begin{tabular}{|c|c|}
\hline Teachers see students as... & Students see teachers as... \\
\hline - $\quad$ Too relaxed when facing problems & - Unable to show leadership skills \\
\hline - Having a "copy \& paste" attitude & - Willing to deny any natural ambiguity \\
\hline $\begin{array}{l}\text { - Expecting them to be the source of every } \\
\text { truth }\end{array}$ & $\begin{array}{l}\text { Excessively oriented towards strategies, } \\
\text { measurement, and quantification }\end{array}$ \\
\hline $\begin{array}{l}\text { Unable to perform open book exams, } \\
\text { because they prefer to memorize }\end{array}$ & $\begin{array}{l}\text { - Assuming all the time that their culture is the } \\
\text { best and repeating "When in Rome..." }\end{array}$ \\
\hline
\end{tabular}

In cultures where locus of control is internal, ambiguity is tolerated because it is an efficient way to deal with conflict (buffer conflict by ignoring it). People from these countries can consider trying to control every event as a sign of arrogance and selfishness. From the teachers' point of view, the relaxed attitude towards different events can get on their nerves excessively. Teachers can also be surprised by the necessity of the students to receive precise information and their intention of absorbing any knowledge without processing it (learning by heart). For such students, the learning process can be seen as a one-way communication issue, and trying to input personal ideas may be perceived as an act of arrogance. Questions like "from which page should I study" or comments like "you are the teacher, you should tell us what is interesting and what is not" are common even if they could shock many lecturers not used to dealing with intercultural classes.

\section{Sequentials Vs. Synchronics}

The following chart shows that most of the students of the schools participating to the survey come from synchronic cultures. Nevertheless, most teachers come from sequential cultures. 


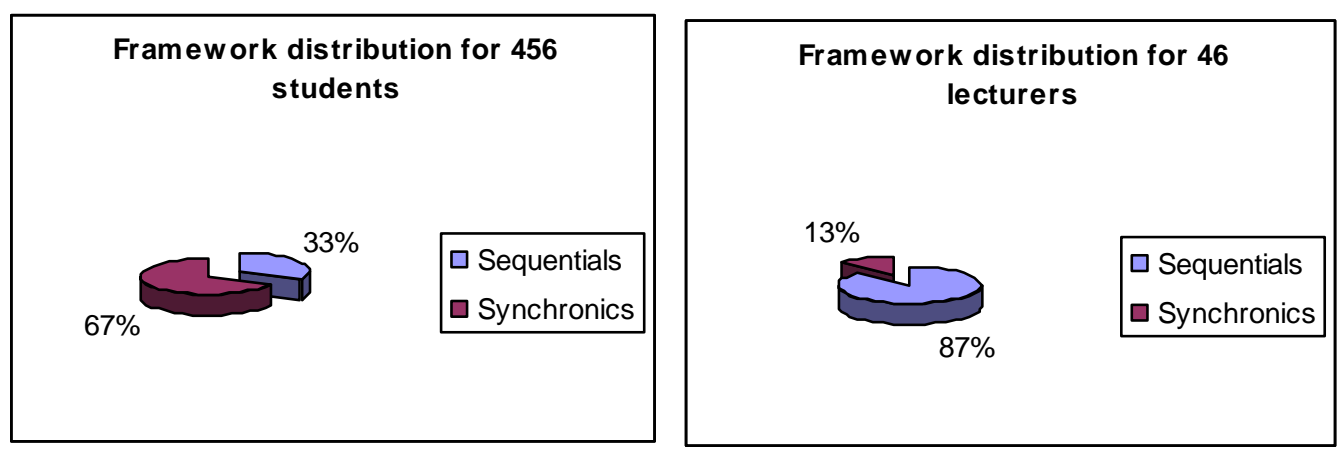

The consequences of this mismatch could be:

\begin{tabular}{|l|l|}
\hline Teachers see students as... & Students see teachers as... \\
\hline$\bullet \quad$ Always being late & $\begin{array}{l}\text { Unable to see that they have many duties to } \\
\text { accomplish (compulsory dinners, kitchen } \\
\text { practices, etc.) }\end{array}$ \\
\hline$\bullet \quad$ Unable to manage their agendas & $\begin{array}{l}\text { Unable to understand that they have a } \\
\text { personal life as well to take care of }\end{array}$ \\
\hline$\bullet \quad$ Studying everything at the last minute & $\bullet \quad$ Providing too much material \\
\hline$\bullet \quad \begin{array}{l}\text { Unable to see the importance of fixing an } \\
\text { appointment for the tutorials (coming to the } \\
\text { office whenever they feel like) }\end{array}$ & $-\quad$ Not giving enough time to study \\
\hline
\end{tabular}

Synchronics can easily make sequentials nervous. Teachers from synchronic cultures need order in their activities. A patchwork of overlapping activities can be both distracting and difficult to manage. On the other side, for synchronics, time is not simply a sequence of passing events, but an illusion in which past (their traditions and living), present (school friends and activities) and the future (job opportunities and relationships with interesting persons) are tightly related. Planning is not a valuable activity for synchronics, because it implies disregarding specific unpredictable events or needs from other people that are vital for their own development. These are even more important than an exam or sticking blindly to an appointment. Anyway in their minds if they are not in the office at the agreed time, they can always come back another day.

\section{Masculinity Vs. Femininity}

The following chart shows that most of the students of the schools participating to the survey (456) come from masculine cultures. 


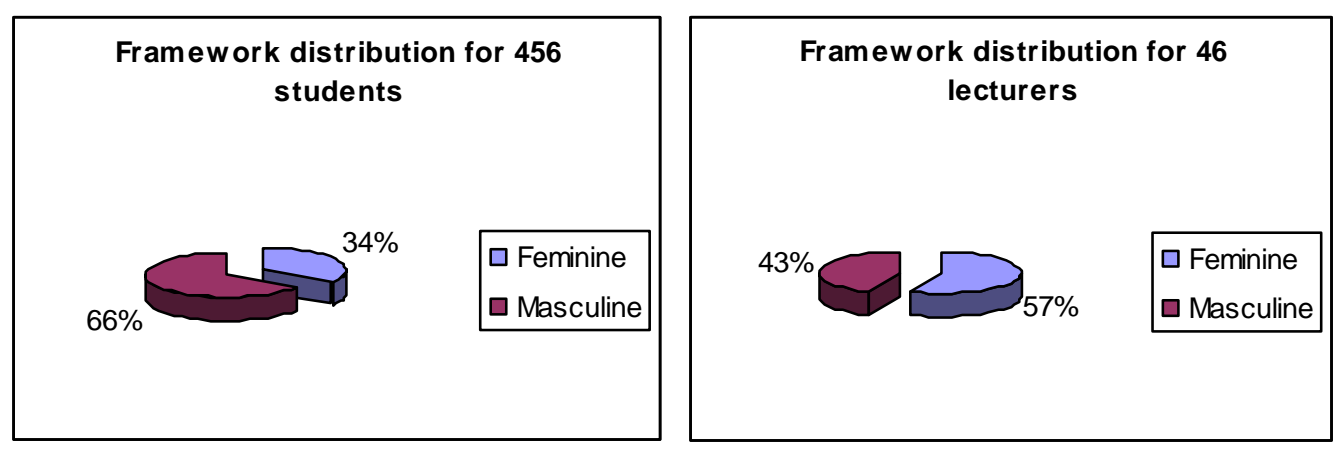

Even if $43 \%$ of the teachers come from masculine cultures as well, the levels of masculinity are gradual (even if Hofstede has presented his frameworks as dichotomies, more than as continuums) and we can assume that most students come from relatively more masculine cultures than their teachers. The consequences of this mismatch could be:

\begin{tabular}{|c|c|}
\hline Teachers see students as... & Students see teachers as... \\
\hline - $\quad$ Aggressive & - Unqualified (if female) \\
\hline - Disrespectful towards females & - Socially dysfunctional \\
\hline - Insubordinate (if teacher female) & $\begin{array}{l}\text { - Selfish and egoist (if female, because no } \\
\text { family or "not taking care of family) }\end{array}$ \\
\hline - Not sensitive to ecology & - Unable to put women at their rightful place \\
\hline
\end{tabular}

With regards to this mismatch, it is female teachers who are the most likely to suffer, because students coming from cultures where women don't hold positions of responsibility will find it difficult to respect them. Especially, if the teachers are rather young, their tasks in the classroom can sometimes be reduced to maintaining discipline. Other aspects such as aggressiveness towards other people and an uncaring attitude towards ecology can also surprise lecturers from feminine cultures.

\section{Universalism Vs. Particularism}

The following chart shows that most of the students of the schools participating to the survey come from particularist cultures.
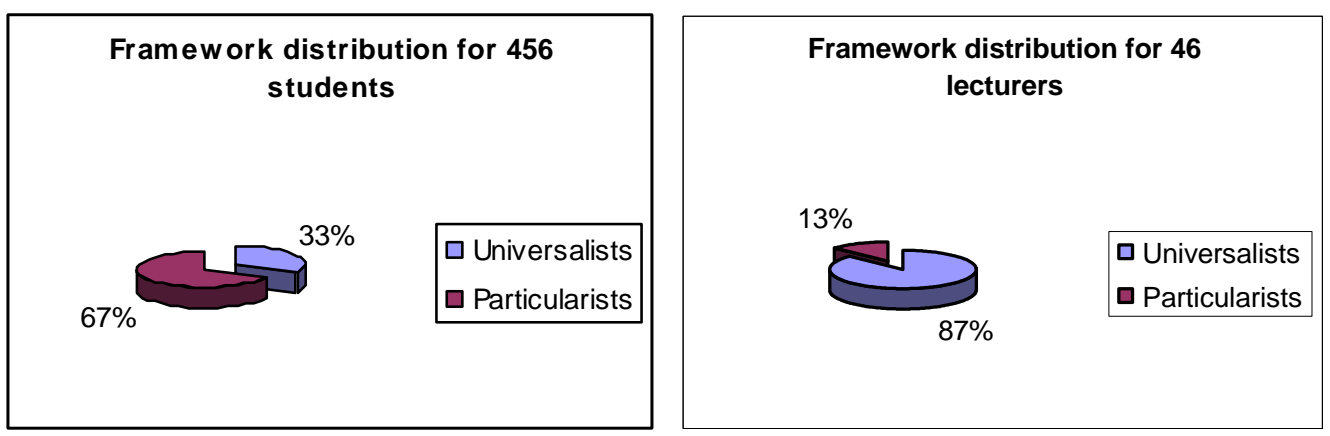
As Switzerland has one of the highest scores in universalism, Swiss teachers, as well as teachers having adapted to this culture, must find it difficult to deal with students making exceptions to every norm stated (or expecting them to make exceptions). On the other hand, students can be astonished when facing their teachers' difficulties in having to look differently look at every particular situation.

\begin{tabular}{|c|c|}
\hline Teachers see students as... & Students see teachers as... \\
\hline - Begging for exceptions all the time & - $\quad$ Tough \\
\hline - $\quad$ Bringing "presents" & - $\quad$ Strict \\
\hline $\begin{array}{l}\text { - Angry when getting low marks } \\
\text { (disappointed) }\end{array}$ & - $\quad$ Severe \\
\hline $\begin{array}{l}\text { - Unable to understand the validity of the rules } \\
\text { and regulations }\end{array}$ & - Iron-hearted \\
\hline - $\quad$ Not serious & - $\quad$ Cold \\
\hline - Unprofessional & - $\quad$ Careless, insensitive \\
\hline
\end{tabular}

\section{Diffuses Vs. Specifics}

The following chart shows that most of the students of the schools participating to the survey come from diffuse cultures.
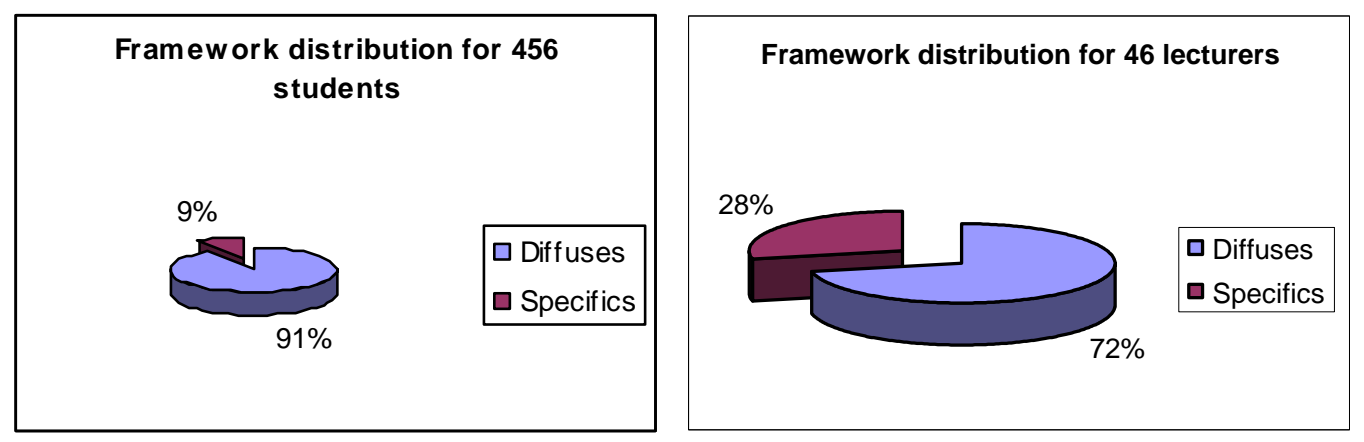

Most students are from diffuse cultures. As teachers normally come from diffuse cultures as well, cultural misunderstandings should not be that frequent at this level. Nevertheless, that some difficulties that a teacher not used to dealing with diffuse cultures could face when dealing with this kind of students.

\begin{tabular}{|c|c|}
\hline Teachers see students as... & Students see teachers as... \\
\hline - $\quad$ Either too distant or too close & - $\quad$ Cheerful \\
\hline $\begin{array}{l}\text { - Expecting the teacher to take care of their } \\
\text { private problems }\end{array}$ & $\begin{array}{l}\text { - Talking about things that nobody should care } \\
\text { about in class (private life and experiences) }\end{array}$ \\
\hline $\begin{array}{l}\text { Treating the teacher as their mum, expecting } \\
\text { them to act not only as a lecturer }\end{array}$ & $\begin{array}{l}\text { - Being very nice and suddenly forgetting } \\
\text { about them when the course is over }\end{array}$ \\
\hline - $\quad$ Lacking a sense of humor & $\begin{array}{ll}\text { - } & \text { Apparently friendly, but actually superficial }\end{array}$ \\
\hline
\end{tabular}

Students of this kind would see their teachers as very open and easy-going, but not really professional. Students would have the impression that teachers are very accessible, but they do not really share anything deep- 
rooted with their students. As well, they could find lack of commitment from the teacher's side because teachers separate private and work life more than people do in diffuse societies. Teachers, on their side, would find it strange that students can easily pass from one extreme to the other, from being very close and difficult to access to extremely trustworthy and unable to restrict their relationship to the professional sphere.

\section{Power Distance}

The following chart shows that most of the students of the schools participating to the survey come from cultures where power distance is high.
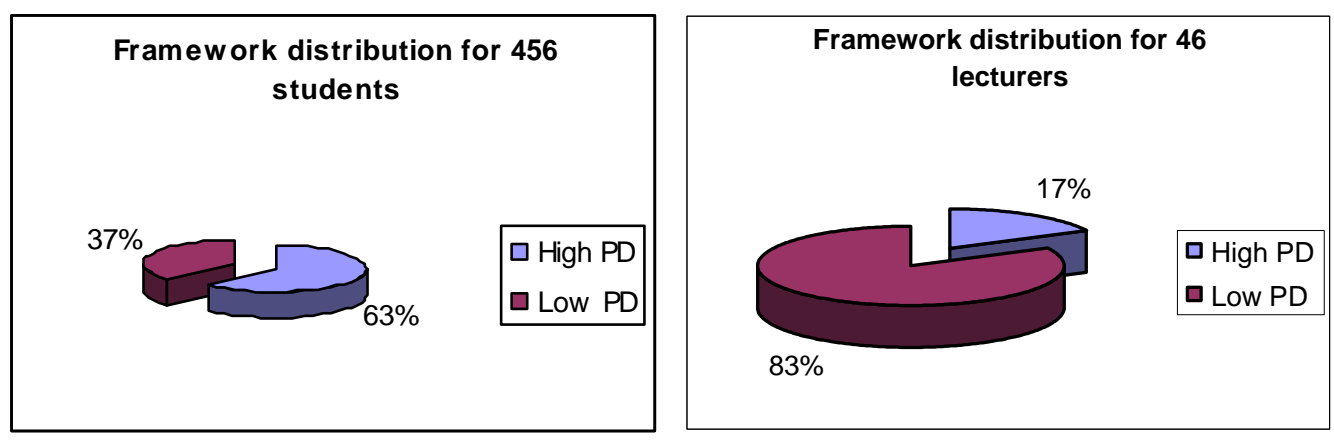

This framework describes how power is distributed in society. Most students come from cultures where power is concentrated in elites, and where most of the population don't have access to most of the benefits held by the top of the hierarchy. Teachers, on the contrary come from countries where power distance is lower.

\begin{tabular}{|c|c|}
\hline Teachers see students as... & Students see teachers as... \\
\hline - $\quad$ Very structured and formal & - Unable to demand submission, so stupid \\
\hline - Annoyingly attached to status symbols & $\begin{array}{l}\text { - Idiots if they change the marks they have } \\
\text { awarded following student's complaints }\end{array}$ \\
\hline $\begin{array}{l}\text { - } \quad \text { Believing they deserve respect because they } \\
\text { are rich }\end{array}$ & $\begin{array}{l}\text { - Daring to give orders to them (the students), } \\
\text { who come from a higher status, class, etc. }\end{array}$ \\
\hline $\begin{array}{ll}\text { - } & \text { Ridiculous (calling teachers "Sir" or even } \\
\text { worse: "Ma'am") }\end{array}$ & - Weak \\
\hline
\end{tabular}

Students coming from power distant cultures would expect someone above them in the hierarchy or in the scale of power to give them strict indications about what they are expected to do or not to do, and even to threaten if their orders are not being followed. If teachers act in a "democratic" way, they are seen as "weak" and therefore not deserving any respect. On the other hand, many students coming to Switzerland to study are part of the elite in their countries, and therefore are used to being spoiled. Assumptions linked to this fact could easily irritate teachers.

\section{Achievers Vs. Ascribers}

The following chart shows that most of the students of the schools participating to the survey come from cultures where ascription is more important than achievement. 

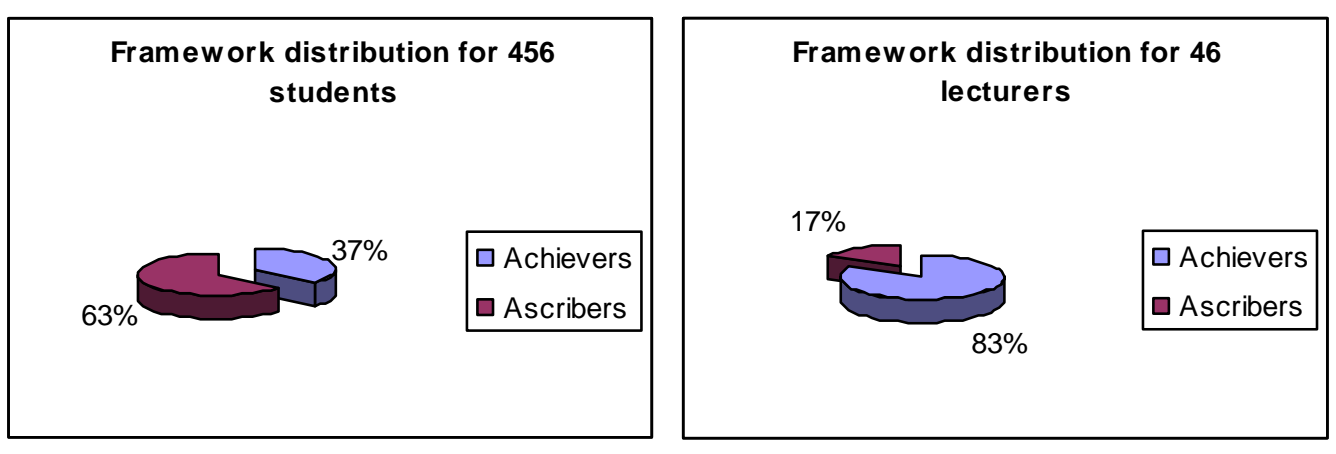

Teachers, on the other hand, come from achieving cultures, so many misunderstandings could take place at this level.

\begin{tabular}{|l|l|}
\hline Teachers see students as... & Students see teachers as... \\
\hline$\bullet \quad$ "Daddy's boys" & $\begin{array}{l}\text { Unable to recognize the importance of their } \\
\text { being part of the most important families in } \\
\text { their home countries }\end{array}$ \\
\hline$\bullet \quad \begin{array}{l}\text { Thinking they can get everything through } \\
\text { payment }\end{array}$ & $\bullet \quad$ Too young to come and teach them \\
\hline$\bullet \quad$ Treating them as servants & $\bullet \begin{array}{l}\text { Women (not qualified enough to teach } \\
\text { certain subjects) }\end{array}$ \\
\hline$\bullet \quad \begin{array}{l}\text { Not being used to working as everyone else } \\
\text { does }\end{array}$ & $\bullet \begin{array}{l}\text { Having low rank level in society (and } \\
\text { therefore deserving to be treated badly) }\end{array}$ \\
\hline
\end{tabular}

In ascribing cultures, status (being) is more important than achieving (doing), so the energy, enthusiasm and capacities of a teacher who does not match the idea of a "respectable person" (usually older men and of a certain social rank) can be fruitless and not taken into consideration.

Teachers, on the other hand, might have problems in understanding why students would give so much importance to issues that are not directly related to their actual capacities, but to more superficial matters.

\section{Uncertainty Avoidance}

The following chart shows that most of the students of the schools participating to the survey come from cultures where uncertainty is meant to be avoided rather than sought. 

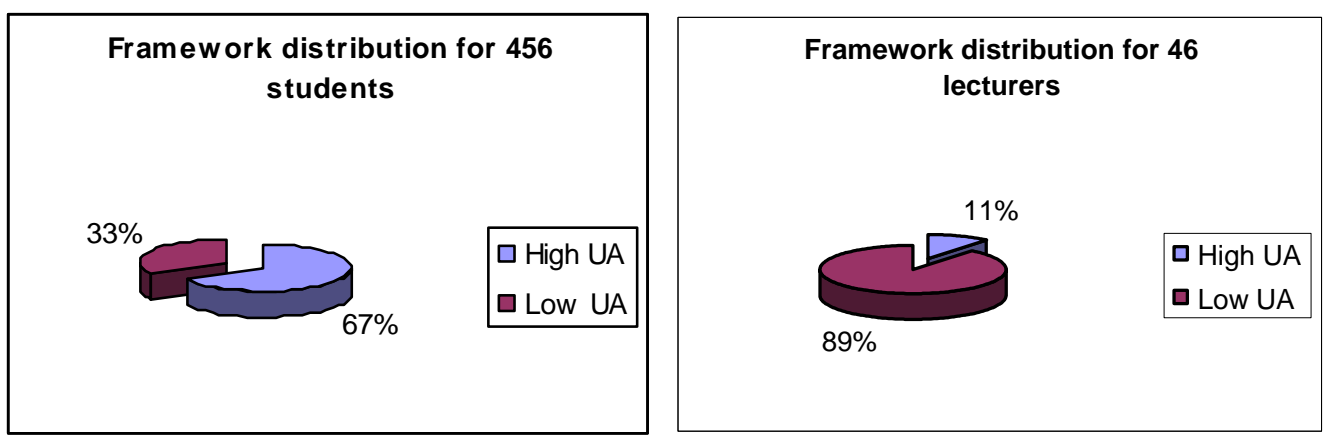

Teachers, on the other hand, are more eager to use methods that imply some ambiguity in the relationship with reality and truth (case methods rather than more Cartesian teaching). This would imply some problems because students would assume that what they are learning are not absolute truths they can blindly trust, but merely intuitive approximations.

\begin{tabular}{|c|c|}
\hline Teachers see students as... & Students see teachers as... \\
\hline $\begin{array}{l}\text { - Willing to stick to tricks, or tips instead of } \\
\text { risking having their own opinion }\end{array}$ & - Unable to get to the point \\
\hline $\begin{array}{l}\text { - Preferring to learn by heart than to be } \\
\text { creative }\end{array}$ & $\begin{array}{l}\text { - Asking to imagine things whereas they are } \\
\text { not in an Art school }\end{array}$ \\
\hline $\begin{array}{l}\text { - Unable to draw conclusions from } \\
\text { experiences }\end{array}$ & - Unable to give norms \\
\hline $\begin{array}{l}\text { - Too much attached to tradition and religious } \\
\text { beliefs }\end{array}$ & $\begin{array}{l}\text { - Disrespectful of the students' religious } \\
\text { beliefs or traditions }\end{array}$ \\
\hline
\end{tabular}

An important issue with regards to this dimension is the importance that cultures with high uncertainty avoidance levels give to religion. Teachers from cultures with low uncertainty avoidance would tend to talk about beliefs quite freely and "objectively", whereas students could feel aggressed by this behaviour and think that the teacher is being disrespectful.

\section{Emotionals Vs. Neutrals}

The following chart shows that most of the students of the schools participating to the survey come from neutral cultures.
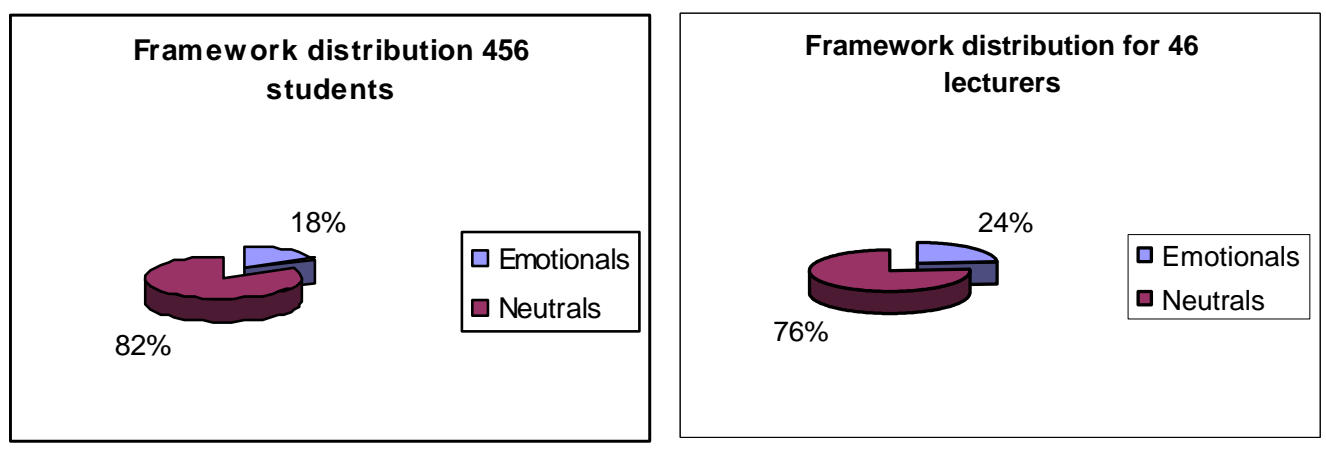
Teachers, as well as students, come from neutral cultures. They tend not to show emotions openly because this would disturb the normal functioning of the academic activities. If, however, most of the teachers were emotional, problems appearing to them would be:

\begin{tabular}{|c|c|}
\hline Teachers see students as... & Students see teachers as... \\
\hline $\begin{array}{l}\text { They are fake (you don't know what they are } \\
\text { really thinking about you) }\end{array}$ & - $\quad$ They are fake (they exaggerate their feelings) \\
\hline - You never know whether they like you or not & $\begin{array}{l}\text { - Always undertaking disciplinary methods } \\
\text { only based on their mood }\end{array}$ \\
\hline - $\quad$ Tough & - Irritable \\
\hline - $\quad$ Not funny & - Unpredictable \\
\hline
\end{tabular}

It would be important for an emotional teacher to know that if a student does not show any emotions when being told off or criticised, it does not necessarily imply that the student does not care. It just implies that he is not showing whether he cares or not. It is important to keep this in mind at all times, in order not to overreact and unnecessarily humiliate the student in case he has failed to achieve the teacher's objectives.

\section{CONCLUSION}

We have come up to the conclusion that the countries where most of the teachers come from have cultural characteristics that are different from those of the students they are working with. This implies that successful teachers working in this environment have to be open-minded enough to be able to deal with persons having different mental programmings and values-- or that in the selection process, only those instructors holding personal characteristics compatible with those accepted by the culture of the student population are privileged.

We must presume, then, that the corporate culture of these schools must be very strong in order to be able to assimilate these two different worlds and allow the companies to make profits despite all these apparently incompatible visions and behavior coexisting (in a determined space). We can presume that it must be difficult for these schools to recruit teachers who have at the same time the necessary knowledge to perform their academic activities and the right personality to cope with such a diverse environment, very often challenging $n$ their own ways of understanding reality. Their personalities may have to be very complex and able to constantly challenge their own convictions and assumptions and have some components appreciated in different cultures as well (ex. a very familyoriented person coming from an individualistic country or a very ecology-oriented person coming from a masculine country). This two-level analysis (personal characteristics of teachers matching the national culture of the students) becomes necessary to understand this phenomenon of discovering patterns of one's own culture in people from other cultures, and what's more, liking them for that.

Students may still prefer to find in their teachers the role model their cultures have constructed for them. Nevertheless, the open-mindness of most hospitality management teachers has been able to overcome this bias and use their own cultural diversity as a means of personal enrichment for both parties, more than an excuse for lower performance. Maybe that is why we enjoy working where we are working.

\section{BIBLIOGRAPHY}

1. Al-Aiban, K. M. \& Pearce, J. L. (1993). The Influence of Values on Management Practices. In Int. Studies of Mgt. \& Org., Vol.23, pp. 35-52. ME Sharpe, Inc.

2. Belle, F (2000). Introduction Générale à la Négociation. From her working papers used at Université Pierre MendèsRance, ESA, Grenoble, France.

3. Berger, P. \& Luckmann, T. (1996). The social construction of reality: a treatise in the Sociology of Knowledge. Masson/Armand Colin, Paris.

4. Bollinger, D. \& Hofstede, G. (1987). Les différences culturelles dans le management: comment chaque pays gère ses hommes. Editions de l'organisation. Paris.

5. D'Iribarne, Ph., Henry, A., Segal, J-P, Chevrier, S., \& Globokar, T. (1998). Culture et Mondialisation: gérer par delà les frontières. Ed. du Seuil. 
6. Enrègle, Y. (1985). Du conflit à la motivation: la gestion sociale. Les éditions d'organisation. Paris.

7. Giddens, A. (1987) La constitution de la société. Presses Universitaires de France, Paris.

8. Hofstede, G. (1984). Culture's consequences: international differences in work-related values (abridged). Beverly Hills. London.

9. Hofstede, G. (1994). Vivre dans un monde multiculturel. Editions de l'organisation. Paris.

10. Kotter, J. (1992). Corporate Culture \& Performances. Free Press.

11. Parsons, T. On the Concept of Political Power. In R. Bendix and S.M. Lipset eds. Class, status, power. 1963.

12. Parsons, T. The Distribution of Power in American Society, World Politics, 10, 1957, 123-43, reprinted in T. Parsons, Structure and Process in Modern Societies.

13. Parsons, T. Social Structure and Personality. Free Press. 1964.

14. Sainsaulieu, R. (1995). Organisation, Culture et Developpement. Ed. Presse Science Po et Dalloz.

15. Saner, R. \& Yiu, L. (1993). Conflict Handling Styles in Switzerland. In Die Unternehmung.

16. Trompenaars, F. \& Hampden-Turner, Ch. (2001). Riding the Waves of Culture. Nicholas Brealey Publishing. London.

17. Trompenaars, F. \& Hampden-Turner, Ch. (1993). The Seven Cultures of Capitalism._Double-day, New York.

\section{Appendix I: Population Of Students By Nationality}

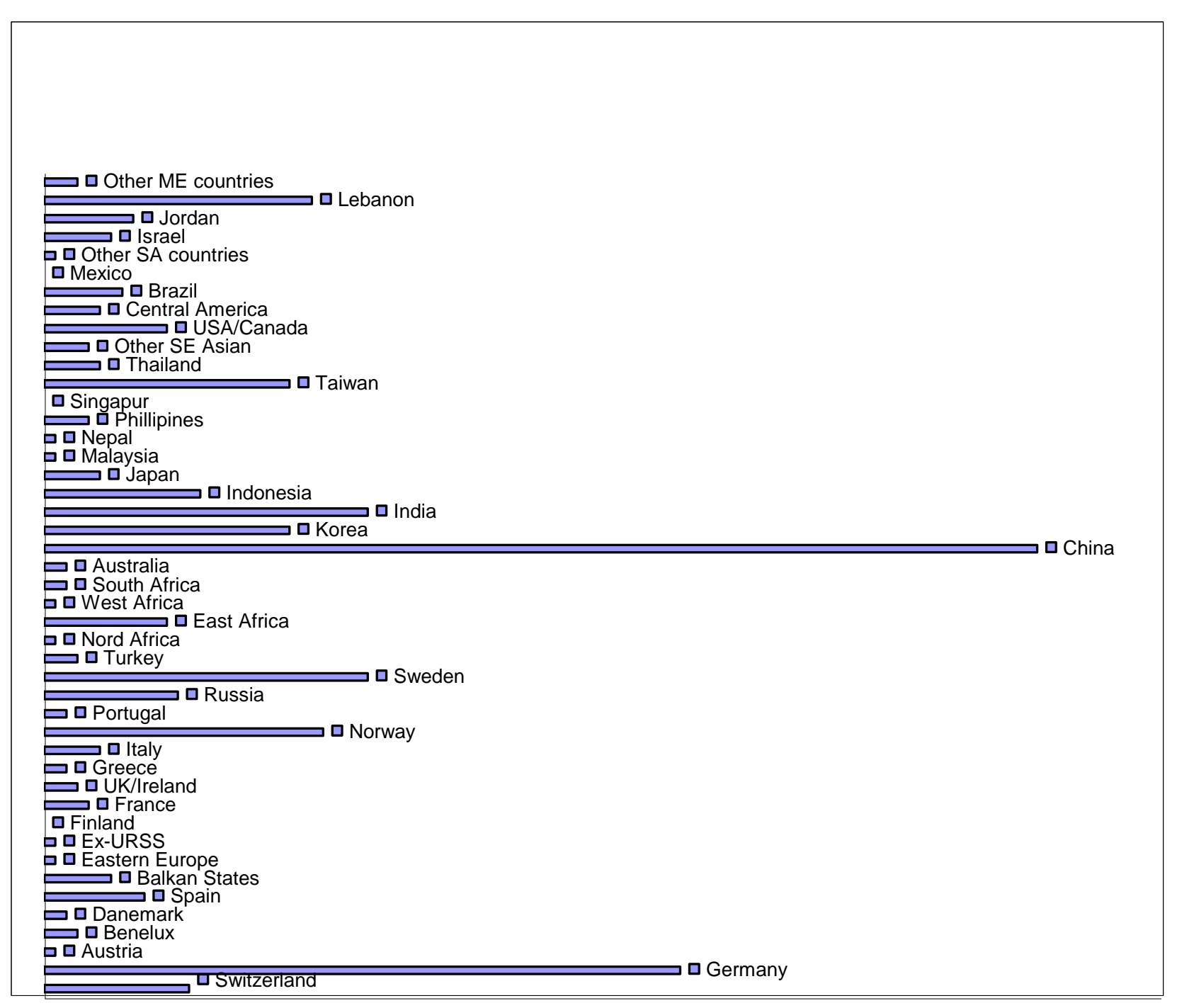


Appendix II: Population Of Teachers By Nationality

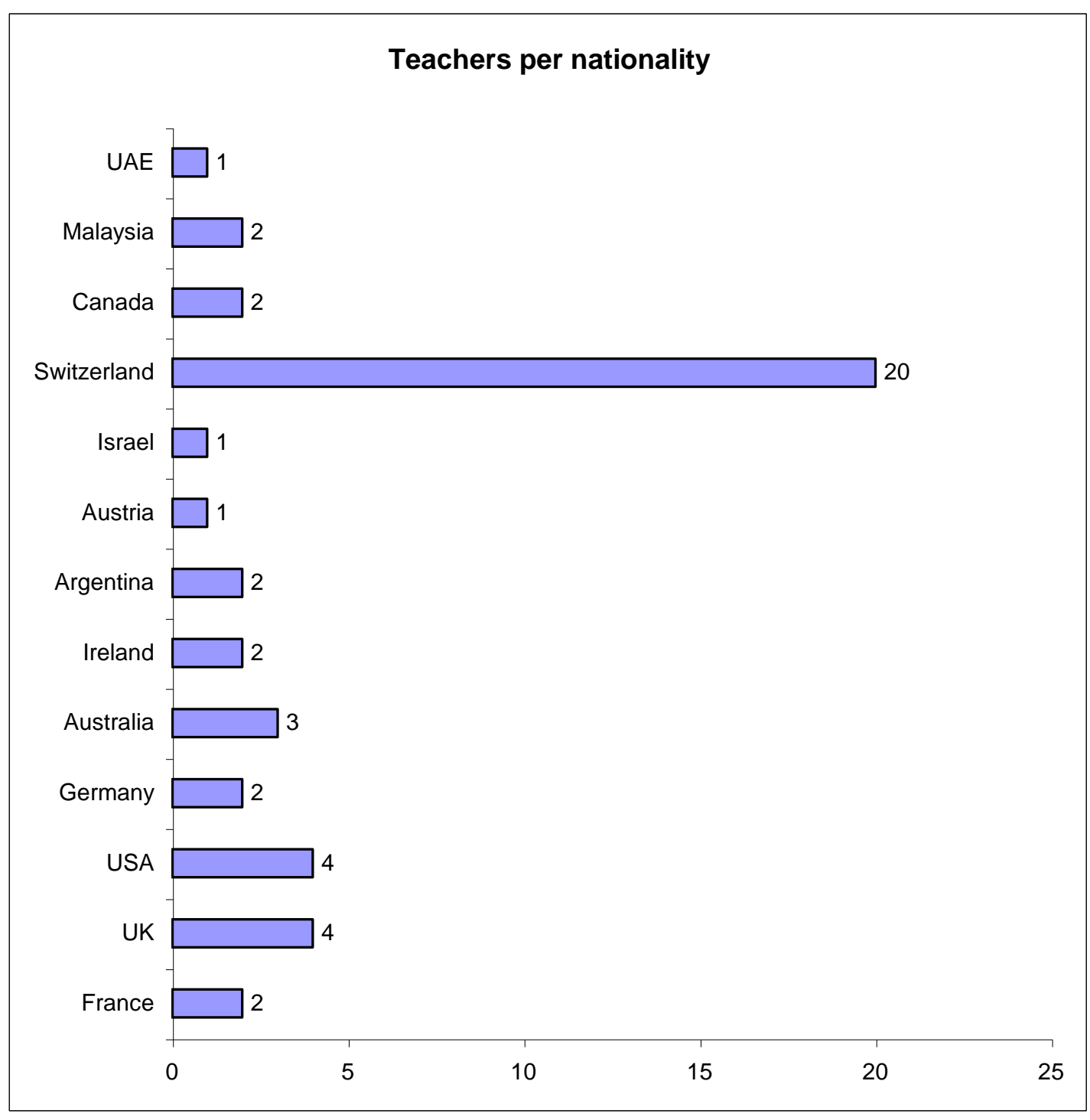

